\title{
DISTAL HUMERAL FRACTURE: AN EPIDEMIOLOGICAL ANALYSIS OF ORTHOPEDIC PATIENTS FOR CHILDREN
}

\section{FRATURA DE ÚMERO DISTAL: UMA ANÁLISE EPIDEMIOLÓGICA DE PACIENTES ORTOPÉDICOS INFANTIS}

\author{
José Carlos Figueiredo fernandes Junior ${ }^{1}$, taiuã Vardasca Milan ${ }^{2}$, Helio augusto Martins Ferreira Ribeiro ${ }^{3}$, \\ Helena Elisa Stein ${ }^{4}$, Hamilton Carmargo Ribas Filho ${ }^{4}$, Beatriz Canhoto Carula ${ }^{4}$
}

1. Universidade Federal de São Paulo, São Paulo, SP, Brazil.

2. Hospital Angelina Caron, Campina Grande do Sul, PR, Brazil.

3. Hospital Marieta Konder Bornhausen, Itajaí, SC, Brazil.

4. Hospital Dr Jesser Amarante Faria, Joinville, SC, Brazil.

\section{ABSTRACT}

Objective: To analyze the epidemiological profiles of children with orthopedic distal humerus fractures. Methods: An analytical descriptive study was conducted with a retrospective approach using medical records of 665 orthopedic children who attended the Jesser Amarante Faria Children's Hospital, a reference hospital in the city of Joinville, Santa Catarina, between June 2012 and December 2016. Results: The results showed a predominance of male patients (64.2\%), with a mean age of 7 years, and the age group of 6-10 years being the most frequent with 319 patients (48\%). The main mechanism of trauma was fall of height in $59.7 \%$ of patients, Gartland type 1 fracture in $57.1 \%$, and absence of vascular injury in $99.7 \%$. Conservative management was implemented in $64.7 \%$ (95\%) of patients. Absence of neurological lesion (95.6\%) and closed lesion (99.4\%) were the main epidemiological characteristics of patients in the study. A low complication rate was observed, with reduction losses in $1.7 \%$ of patients, followed by infections in $1.1 \%$. Conclusion: We can conclude that the cases studied presented epidemiological characteristics similar to those described in the literature. Level of evidence IV, Description of a case series, with analysis of results, without a comparative study.

Keywords: Humeral fractures, Supracondylar, Elbow fracture, Pediatric.

\section{RESUMO}

Objetivo: Analisar o perfil epidemiológico de pacientes ortopédicos infantis com fratura de úmero distal. Método: Estudo analítico-descritivo, com abordagem retrospectiva dos prontuários médicos de 665 pacientes ortopédicos infantis, atendidos no Hospital Infantil Dr. Jeser Amarante Faria, referência no município de Joinville (SC), do período de junho de 2012 a dezembro de 2016. Resultados: Os resultados mostraram um predomínio de pacientes do sexo masculino $(64,2 \%)$, com idade média de 7 anos, sendo a faixa etária de 6 a 10 anos a mais frequente, com 319 (48\%) pacientes. O principal mecanismo do trauma foi por queda da própria altura (59,7\%), com Gartland 1 em $57,1 \%$ dos casos e ausência de lesão vascular (99,7\%). A conduta conservadora foi observada em $64,7 \%$ dos pacientes, além de ausência de complicações imediatas (97,1\%), complicações tardias (95,3\%) e lesão neurológica (95,6\%). Lesão fechada (99,4\%) foi a principal característica epidemiológica dos pacientes estudados. Uma baixa frequência de complicações foi observada, sendo mais prevalentes as perdas de reduções (1,7\%), seguidas de infecções, em 1,1\% dos casos. Conclusões: Os casos estudados apresentaram características epidemiológicas semelhantes àquelas descritas na literatura. Nível de evidência IV, Descrição de série de casos, com análise de resultados, sem estudo comparativo.

Descritores: Fratura do úmero. Supracondiliana. Fratura do cotovelo, pediatrica.

Citation: Fernandes Jr JCF, Milan TV, Ribeiro HAMF, Stein HE, Filho HCR, Carula BC. Distal humero fracture: an epidemiological analysis of orthopedic patients for children. Acta Ortop Bras. [online]. 2019;27(5):261-4. Available from URL: http://www.scielo.br/aob.

\section{INTRODUCION}

Within the fractures of the elbow in infancy, supracondylar fractures represent the majority with $55 \%$, being the second most common fracture in infancy, accounting for $15 \%$ of all childhood fractures. There is a predominance in males where the right upper limb is the most affected. The mean age of children affected by this pathology is 5-7 years ${ }^{1}$.
Supracondylar humeral fractures in children are divided into extension or flexion. Those in extension correspond to up to $95 \%$ of the cases, while in flexion they occur from 5 to $10 \%$. Falls are the main mechanism of trauma of this pathology varying according to the attitude of the limb at the time of the trauma, or in the extension or flexed. Due to the proximity to noble structures this type of fracture

All authors declare no potential conflict of interest related to this article.

This work was performed at the Hospital Infantil Dr. Jesser Amarante Faria, Joinville, SC, Brazil.

Correspondence: José Carlos Figueiredo Fernandes Junior. Rua Agostinho Gomes 1326 apt 2122 Bairro Ipiranga, São Paulo, SP, Brazil. jjernandes2@Hotmail.Com 
presents important complications, being the lesion of the brachial artery and the radial nerve the most common lesions ${ }^{1}$.

The most used classification is Gartland, which subdivides them into 3 types, namely type I: the displacement is minimal or non-existent where the fracture can be visualized on radiographs, and the sign of the fat pad may be observed, type II: Although the fracture has posterior displacement, the posterior integrity of the bone cortex is preserved and type III: there is displacement and interruption in the posterior cortical bone with loss of contact between fragments. The distal fragment is shifted posteriorly and proximally by triceps contraction in extension fractures. In the flexural fractures, the displacement of the distal fragment occurs anteriorly ${ }^{1}$.

Some studies report that the age and severity of the fracture, identified by the Gartland criteria, have a prognostic value in the final range of motion of the elbow. The recover after these fracture, but they have long-term complications. It was observed that the majority of Gartland type I fractures presented good results, and types II and III were varied according to the personality of each fracture.

During the bibliographic research on the topic, it was verified the existence of several studies involving fractures of the distal humerus in children, some analyzing the epidemiology and others evaluating the surgical technique of approach, pointing out that it is necessary a regional study that provides reliable data.

Having knowledge about the affected population and its particularities, as the age group with the highest incidence, as well as of greater severity, can assist in the assembly of specific strategies for each group, providing better assistance to these Patients both in intra and extra-hospital environment.

Thus, patients benefit from adequate and optimized guidance and follow-up, aimed at their age group and associated conditions, avoiding not only outcomes such as death, but also sequelae, resulting in a better quality of life post-intervention.

This research aimed to perform an epidemiological analysis of pediatric orthopedic patients, with fracture of the distal humerus, attended in the emergency room of the Pediatric Hospital Dr. Jesser Amarante Faria in the period from June 2012 to December 2016.

\section{MATERIAL AND METHODS}

Analytical-descriptive and retrospective study of 665 medical records of patients attended at the Pediatric Hospital Dr. Jesser Amarante Faria -HJAF, reference in the municipality of Joinville Santa Catarina, from June 2012 to December of 2016.

Patients with distal humeral fracture treated at the HJAF in the aforementioned period were included in this project, which information from their medical records responded to at least 6 questions of the established protocol. Patients with other types of fracture were excluded from the research and also those who did not present information that answered at least 6 questions of the research protocol. Descriptive and inferential statistical methods were applied to analyze the data of orthopedic patients seen in the HJAF, being presented as graphs and tables and interpreted from the descriptive statistics with the help of the program BioEstat version 5.3.

All the patients involved in the research were evaluated according to the precepts of the Declaration of Helsinque and the Nuremberg code, respecting the norms of research involving human beings (resolution No. 196/96) of the National Health Council, guaranteeing the Confidentiality of patient identification. This work was submitted to the ethics committee, being approved on 06/14/17 (caae: 66741317.3.0000.5363)

\section{RESULTS}

The present study analyzed data from $n=665$ trauma patients, attended at a children's hospital. These patients are $64.2 \%$ male (415 patients) and $37.6 \%$ female (250 patients). The age distribution of the patients had a mean of 7.2 years with a standard deviation of 3.6 years, being the age group of 6 to 10 years the most frequent with 319 patients (48\%), as you can see in Table 1.

The sample distribution according to the patient's age range shows that the expected values are as follows: from 0 to 2 years (4.1\%), from 3 to 5 years (31.7\%), from 6 to 10 years $(47.8 \%)$ and adolescents $(16.4 \%)$. These are the main characteristics found in the medical records: mechanism of trauma due to fall of own height (59.7\%), with Gartland I (57.1\%), absence of vascular injury (99.7\%), being found only in 2 patients with vascular injury, conduct Conservative $64.7 \%$, absence of immediate complications $97.1 \%$, absence of late complications 95.3\%, absence of neurological injury $95.6 \%$ and closed lesion $99.4 \%$.

Table 1. Epidemiological profile of patients with distal humeral fracture, attended at the Pediatric Hospital Dr. Jesser Amarante Faria - HJAF, in the city of Joinville - Santa Catarina, from June 2012 to December 2016.

\begin{tabular}{|c|c|c|c|c|c|c|c|}
\hline \multirow{2}{*}{ Socio-demographic profile } & \multicolumn{2}{|c|}{ Male } & \multicolumn{2}{|c|}{ Female } & \multicolumn{2}{|c|}{ Total } & \multirow{2}{*}{ P-value } \\
\hline & $n$ & $\%$ & $\mathrm{n}$ & $\%$ & $n$ & $\%$ & \\
\hline Age & & & & & & & $0.0015^{\star \star}$ \\
\hline 0 to 2 years & 14 & 3.4 & 13 & 5.2 & 27 & 4.1 & \\
\hline 3 to 5 years & 113 & 27.2 & 99 & 39.6 & 212 & 31.9 & \\
\hline 6 to 10 years & 210 & 50.6 & 109 & 43.6 & 319 & 48.0 & \\
\hline Uninformed & 78 & 18.8 & 29 & 11.6 & 107 & 16.1 & \\
\hline Trauma Mechanism & & & & & & & $0.5779^{\text {ns }}$ \\
\hline Running over injuries & 6 & 1.4 & 2 & 0.8 & 8 & 1.2 & \\
\hline Fall from own height & 244 & 58.8 & 153 & 61.2 & 397 & 59.7 & \\
\hline Agression & 2 & 0.5 & 0 & 0 & 2 & 0.3 & \\
\hline Fall/Height & 133 & 32.0 & 77 & 30.8 & 210 & 31.6 & \\
\hline Uninformed & 30 & 7.2 & 18 & 7.2 & 48 & 7.2 & \\
\hline Diagnostic & & & & & & & $0.0025^{\star \star}$ \\
\hline GARTL I & 220 & 53.0 & 160 & 64.0 & 380 & 57.1 & \\
\hline GARTL II & 65 & 15.7 & 42 & 16.8 & 107 & 16.1 & \\
\hline GARTL III & 130 & 31.3 & 48 & 19.2 & 178 & 26.8 & \\
\hline Vascular injury & & & & & & & $0.7143^{\mathrm{ns}}$ \\
\hline Present & 2 & 0.5 & 0 & 0 & 2 & 0.3 & \\
\hline Absent & 413 & 99.5 & 250 & 100 & 663 & 99.7 & \\
\hline Conduct & & & & & & & $0.0129^{*}$ \\
\hline Conservative & 253 & 61.0 & 177 & 70.8 & 430 & 64.7 & \\
\hline Surgical & 162 & 39.0 & 73 & 29.2 & 235 & 35.3 & \\
\hline Immediate Complications & & & & & & & $0.3287^{\mathrm{ns}}$ \\
\hline Absent & 401 & 96.6 & 245 & 98 & 646 & 97.1 & \\
\hline Compartment Syndrome & 0 & 0.0 & 1 & 0.4 & 1 & 0.2 & \\
\hline Infection & 5 & 1.2 & 2 & 0.8 & 7 & 1.1 & \\
\hline Loss of reduction & 9 & 2.2 & 2 & 0.8 & 11 & 1.7 & \\
\hline Late Complications & & & & & & & $0.7798^{\text {ns }}$ \\
\hline Absent & 393 & 94.7 & 241 & 96.4 & 634 & 95.3 & \\
\hline Infection & 7 & 1.7 & 3 & 1.2 & 10 & 1.5 & \\
\hline Vicious consolidations & 1 & 0.2 & 0 & 0 & 1 & 0.2 & \\
\hline Angular deformities & 4 & 1.0 & 1 & 0.4 & 5 & 0.8 & \\
\hline Joint Stiffness & 10 & 2.4 & 5 & 2 & 15 & 2.3 & \\
\hline Neurological Injury & & & & & & & $0.3007^{\mathrm{ns}}$ \\
\hline Absent & 394 & 94.9 & 242 & 96.8 & 636 & 95.6 & \\
\hline Radial & 12 & 2.9 & 2 & 0.8 & 14 & 2.1 & \\
\hline Median & 4 & 1.0 & 3 & 1.2 & 7 & 1.1 & \\
\hline Ulnar & 5 & 1.2 & 3 & 1.2 & 8 & 1.2 & \\
\hline Closed or Exposed & & & & & & & $0.9986^{\mathrm{ns}}$ \\
\hline Closed & 413 & 99.5 & 248 & 99.2 & 661 & 99.4 & \\
\hline Exposed & 2 & 0.5 & 2 & 0.8 & 4 & 0.6 & \\
\hline
\end{tabular}

Source: Medical records of the Pediatric Hospital Dr. Jesser Amarante Faria - HJAF (2018). Pearson's chi-squared test for trend. ** Highly significant values; *Significant values; ${ }^{\text {NS N Non }}$ significant values. $H_{1}$ : There is a significant trend in the level $0.05(p<0.05)$. 
On the other hand, the variables that presented real association with the sex of the patient were these. Age ( $P=0.0015$ *, statistically significant) in the range of 3 to 5 years: male (27.2\%) and female (39.6\%). Gartland III ( $p=0.0025$ *, statistically significant): male $(31.3 \%)$ and female (19.2\%). The surgical procedure $(p=0.0129$ *, statistically significant): male (39\%) and female (29\%).

It was found that both in the immediate complications $(P<0.0001$ *) and in the late complications $\left(P<0.0001^{\star}\right)$ There was a statistically significant predominance for conservative conduct with no complications.

The evaluation of the diagnosis showed A highly significant tendency $\left(P<0.0001^{*}\right)$ to: Gartland I Conservative conduct $87.2 \%$ and surgical Conduct-Gartland III 74.2\% (Table 2).

The evaluation of Gartland according to the immediate complications resulted in the P-value $<0.0001$ * (highly significant) indicating that in Gartland I absence of complication is more frequent in conservative conduct (99.8\%). The evaluation of the conduct according to the late complications resulted in the P-value $<0.0001$ * (highly significant) indicating that the absence of complication is more frequent in the conservative conduct (99.8\%). The evaluation of the conduct according to Gartland resulted in the P-value $<0.0001$ * (highly significant) indicating that Gartland III is more frequent in the surgical conduct (74.0\%), and its demonstrated in Table 3.

Table 2. Distribution of patients with distal humeral fracture, attended at Pediatric Hospital Dr. Jesser Amarante Faria - HJAF, in the municipality of Joinville - Santa Catarina, in the period from June 2012 to December 2016, according to the type of conduct and the presence of complications and diagnosis.

\begin{tabular}{|c|c|c|c|c|c|c|c|}
\hline \multirow{3}{*}{ Clinic Profile } & \multicolumn{5}{|c|}{ Conduct } & & \multirow{3}{*}{ P-Value ${ }^{1}$} \\
\hline & \multicolumn{2}{|c|}{ Conservative } & \multicolumn{2}{|c|}{ Surgical } & \multicolumn{2}{|c|}{ General } & \\
\hline & $\mathbf{n}$ & $\%$ & $\mathrm{n}$ & $\%$ & $\mathbf{n}$ & $\%$ & \\
\hline Immediate Complications & & & & & & & $<0.0001^{* *}$ \\
\hline Absent & 428 & 99.8 & 218 & 92.4 & 646 & 97.1 & \\
\hline Compartmental Syndrome & 0 & 0.0 & 1 & 0.4 & 1 & 0.2 & \\
\hline Infection & 0 & 0.0 & 7 & 3.0 & 7 & 1.1 & \\
\hline Loss reduction & 1 & 0.2 & 10 & 4.2 & 11 & 1.7 & \\
\hline Late Complications & & & & & & & $<0.0001^{\star *}$ \\
\hline Absent & 428 & 99.8 & 205 & 86.9 & 633 & 95.2 & \\
\hline Infection & 0 & 0.0 & 10 & 4.2 & 10 & 1.5 & \\
\hline Vicious consolidations & 0 & 0.0 & 1 & 0.4 & 1 & 0.2 & \\
\hline Angular deformities & 1 & 0.2 & 4 & 1.7 & 5 & 0.8 & \\
\hline Joint Stiffness & 0 & 0.0 & 15 & 6.4 & 15 & 2.3 & \\
\hline Diagnostic & & & & & & & $<0.0001^{* *}$ \\
\hline GARTL I & 374 & 87.2 & 6 & 2.5 & 380 & 57.1 & \\
\hline GARTL II & 52 & 12.1 & 55 & 23.3 & 107 & 16.1 & \\
\hline GARTL III & 3 & 0.7 & 175 & 74.2 & 178 & 26.8 & \\
\hline
\end{tabular}

Source: Medical records of the Pediatric Hospital Dr. Jesser Amarante Faria - HJAF (2018) Pearson's chi-squared test for trend. ** Highly significant values; *Significant values; ${ }^{\text {NS Non }}$ significant values. $H_{1}$ : There is a significant trend in the level $0.05(p<0.05)$

\section{DISCUSSION}

In our series, the most significantly affected age are between 6 and 10 years old, with an average of 7.2 years, similar to other studies in which the described media age is around 7.9 years as found in Houshian's work. In relation to gender, the highest prevalence in boys was $64.2 \%$ of males in relation to $37.7 \%$ of females, which corresponds with the study of Houshian ${ }^{6}$, but diverges from the work of Barr ${ }^{1}$ that found a higher prevalence in girls.

It was not possible to define the most affected dominance due to the lack of data in the medical records, but a higher frequency of involvement of the left arm was verified in relation to the right
Table 3. Distribution of patients with distal humeral fracture, attended at the Pediatric Hospital Dr. Jesser Amarante Faria - HJAF, in the municipality of Joinville - Santa Catarina, from June 2012 to December 2016, according to the Gartland classification and the presence of complications.

\begin{tabular}{|c|c|c|c|c|c|c|c|}
\hline \multirow{3}{*}{ Clinic Profile } & \multicolumn{6}{|c|}{ GARTLAND Classification } & \multirow{3}{*}{ P-value ${ }^{1}$} \\
\hline & \multicolumn{2}{|c|}{ GI } & \multicolumn{2}{|c|}{ G II } & \multicolumn{2}{|c|}{ G III } & \\
\hline & $\mathbf{n}$ & $\%$ & $\mathrm{n}$ & $\%$ & $\mathrm{n}$ & $\%$ & \\
\hline Immediate Complications & & & & & & & $<0.0001^{\star *}$ \\
\hline Absent & 380 & 100.0 & 102 & 95.3 & 164 & 92.1 & \\
\hline Compartmental Syndrome & 0 & 0.0 & 1 & 0.9 & 0 & 0.0 & \\
\hline Infection & 0 & 0.0 & 0 & 0.0 & 7 & 3.9 & \\
\hline Loss of reduction & 0 & 0.0 & 4 & 3.7 & 7 & 3.9 & \\
\hline Late Complications & & & & & & & $<0.0001^{* *}$ \\
\hline Absent & 380 & 100.0 & 100 & 93.5 & 154 & 86.5 & \\
\hline Infection & 0 & 0.0 & 3 & 2.8 & 7 & 3.9 & \\
\hline Vicious consolidation & 0 & 0.0 & 0 & 0.0 & 1 & 0.6 & \\
\hline Rotation deformity & 0 & 0.0 & 3 & 2.8 & 2 & 1.1 & \\
\hline Joint Stiffness & 0 & 0.0 & 1 & 0.9 & 14 & 7.9 & \\
\hline
\end{tabular}

Source: Medical records of the Pediatric Hospital Dr. Jesser Amarante Faria - HJAF (2018). Pearson's chi-squared test for trend. ** Highly significant values; *Significant values; ${ }^{\text {NS Non }}$ significant values. $H_{1}$ : There is a significant trend in the level $0.05(p<0.05)$

arm, which goes according to the findings of the work of Barr ${ }^{1}$ that Reported an impairment of $59 \%$ on the left side, and Sinikumpu ${ }^{5}$, which found a higher prevalence on the right side.

It was observed a high prevalence of fractures resulting from the fall of the own height (59.7\%), followed by falls of heights (31.6\%), when compared to the work of Barr ${ }^{1}$, we noticed a higher number of falls in height, and we related this fact to the period in which the study was carried out, coinciding with the school vacation period, which makes children more susceptible to falls from heights while they are in the external environment, our work has a longer scope of time not taking into consideration the month in which the trauma occurred. However, this research goes according the results found in the work of Omid, Choi and Skaggs ${ }^{3}$, which attributed the occurrence of falls from their own height to the locality, where there is a predominance of residences without recreational area. We found exposed fracture rates that are compatible with the literature $(0.6 \%$ of all fractures) as well as nerve injury (4.4\%) being the most prevalent of the radial nerve (2.1\%) agreeing with Omid, Choi and Skaggs ${ }^{3}$ and Martini, the same occurs for vascular lesions, which in this research was identified injury in only 2 patients, consistent with the maximum number stipulated by Omid, Choi and Skaggs ${ }^{3}$ who observed that these lesions did not exceed $3 \%$. Considering the total of 655 patients, it was found that $57.1 \%$ of the patients were classified as Gartland 1, according to Barr1 the most common, but diverges from the results presented by Martini ${ }^{6}$ and Omid, Choi and Skaggs ${ }^{3}$, it is believed that these discrepancies are related to kinematics and to the mechanism of trauma, since the patients in this research, as previously mentioned, were victims of low-energy falls, such as falling from their own height, and already in the cited references the mechanism of trauma most common would be the falls of the height, resulting in greater energy.

As for the treatment, there is a supremacy of conservative treatment in relation to surgery, $64.7 \%$ and $35.3 \%$ respectively, this due to the choice to treat type II fractures conservatively in a large number of cases, this way we found a divergence in relation to the data found by Martini ${ }^{6}$, since it had a media of $76 \%$ of the cases, being treated as surgical and correlated this divergence to the prevalence of Gartland III fractures in the cited study.

Regarding the immediate complications, there was a low number of complications in this study, with more prevalent losses of reductions $(1.7 \%)$, followed by infections $(1.1 \%)$, which is within the 
values described in the literature as shown by the review of Omid, Choi and Skaggs ${ }^{3}$.

Reduces losses were related to Gartland II and Gartland III fractures, 4 and 7 patients, respectively. As for the late complications, we found a small number of joint stiffness (15 patients), 14 of whom were initially classified as Gartland III, related to this the time of immobilization and initial severity of the lesion, but all showed improvement after physiotherapy. Considering the deformities, we found a " $n$ " of 5 patients, representing $2.3 \%$ of the patients, within the limits presented by Omid, Choi and Skaggs ${ }^{3}$.

\section{CONCLUSION}

Analyzing the epidemiological profile of patients with distal humeral fracture, a predominance of males with a mean age of 7.2 years was observed, the main mechanism of trauma was the fall of the own height and the most prevalent Gartland classification was Type I. The most accomplished treatment was the conservative with absence of immediate complications and absence of late complications in most cases. Analyzing the conducts according to the Gartland classification it was noted that the type I obtained $87.2 \%$ of the conservative conducts, while Gartland II obtained $23.3 \%$ of the surgical conducts together with type III with $74.2 \%$. Among the immediate and late complications, the Gartland type I fracture did not present any alterations, whereas type II was the main immediate complication of loss of reduction with $3.7 \%$, and $2.8 \%$ of infection and angular deviation as late complications, while observed that type III presented 3.9\% of infection and loss of reduction in immediate complications and $7.9 \%$ of joint stiffness in late complications.

AUTHORS' CONTRIBUTIONS: Each author contributed individually and significantly to the development of this manuscript. JCFFJ (0000-0002-5687-8774)* *: manuscript drafting and review; TVM (0000-0003-1891-5148)*: data analysis and manuscript drafting; HAMFR (000-0002-2633-2463) *: manuscript review; HES (0000-0003-0469-8605)*: study conception and design; HCRF (000-0002-2633-2463)*: manuscript review and the intellectual concept of the article; BCC (0000-0001-9739-4867)*: data collection. *ORCID (Open Researcher and Contributor ID).

\section{REFERENCES}

1. Barr LV. Paediatric supracondylar humeral fractures: epidemiology, mechanisms and incidence during school holidays. J Child Orthop. 2014;8(2):167-70.

2. Martini RK, Fonseca GF, Martini RK, Azeredo Filho M, Serafini OA. Análise das fraturas supracondilianas do úmero em crianças. Acta Ortop Bras. 2002;10(2):25-30.

3. Omid R, Choi PD, Skaggs DL. Supracondylar humeral fractures in children. J Bone Joint Surg Am. 2008;90(5):1121-32.

4. Kang S, Kan M, Miraj F, Park SS. The prognostic value of the fracture level in the treatment of Gartland type III supracondylar humeral fracture in children.
Bone Joint J. 2015;97(1):134-40

5. Sinikumpu JJ, Victorzon S, Pokka T, Lindholm EL, Peljo T, Serlo W. The long-term outcome of childhood supracondylar humeral fractures: A population-based follow up study with a minimum follow up of ten years and normal matched comparisons. Bone Joint J. 2016;98(10):1410-7.

6. Houshian S, Mehdi B, Larsen MS. The epidemiology of elbow fracture in children: analysis of 355 fractures, with special reference to supracondylar humerus fractures. J Orthop Sci. 2001;6(4):312-5. 